\title{
PENGARUH PEMBERIAN HOMECARE MAHASISWI DIII KEBIDANAN PADA IBU HAMIL TRIMESTER III TERHADAP JENIS METODE KB TERPILIH
}

\section{THE EFFECT OF HOMECARE GIVING FOR FEMALE STUDENTS IN DIII MIDWIFERY IN THE THIRD TRIMESTER PREGNANT WOMEN ON THE TYPE OF KB METHOD CHOSEN}

\author{
Ervin Rufaindah \\ STIKES Widyagama Husada Malang \\ Email: ervinrufaindah@yahoo.com
}

\begin{abstract}
ABSTRAK
Penggunaan alat kontrasepsi setelah melahirkan begitu penting untuk mencegah terjadinya kehamilan yang tidak diinginkan. Hampir 80\% akseptor KB memilih KB hormonal, sehingga masyarakat tidak asing lagi dengan KB hormonal. Akan tetapi banyak juga akseptor yang mengeluhkan efek samping KB hormonal sehingga banyak akseptor yang drop out. Salah satu penyebab banyaknya akseptor KB drop out yakni kurangnya pemahaman tentang KB hormonal sehingga perlu pemberian pendidikan kesehatan tentang KB dan metode kontrasepsi untuk meningkatkan kesadaran ibu menggunakan kontrasepsi. Tujuan penelitian ini untuk menganalisis pengaruh pemberian homecare mahasiswi DIII Kebidanan pada ibu hamil trimester III terhadap jenis metode KB terpilih di Malang. Penelitian ini merupakan studi observasional dengan pendekatan cross sectional. Sampel penelitian berjumlah 67 responden. Analisis data menggunakan uji chi-Square. Hasil uji uji chi-Square Pvalue 0,132 > 0,05 yang berarti tidak ada hubungan signifikan antara pelayanan homecare dengan jenis metode KB terpilih setelah melahirkan. Diharapkan mahasiswa, institusi pendidikan dan bidan praktik bersama-sama meningkatkan kualitas pelayanan dengan memberikan KIE yang optimal terkait keluarga berencana dan alat kontrasepsi.
\end{abstract}

Kata kunci : Homecare, Alat Kontrasepsi, Ibu Hamil Trimester III

\section{ABSTRACT}

The use of contraception after childbirth is so important to prevent the occurrence of unwanted pregnancies. Nearly $80 \%$ of family planning acceptors choose hormonal birth control, so people are not familiar with hormonal birth control. However, many acceptors complained about the side effects of family planning so that many acceptors dropped out. One of the causes of the number of family planning acceptors dropping out is the lack of understanding of hormonal family planning so that it is necessary to provide health education about family planning and contraceptive methods to increase maternal awareness of using contraception. The purpose of this study was to analyze the effect of homecare giving from midwifery students in trimester III pregnant women on the type of selected birth control method in Malang. This study was an observational study with a cross-sectional approach. The research sample amounted to 67 respondents. Data analysis using the chi-square test. The result of the chi-square test pvalue is 0.132>0.05, which means there is no significant relationship between home care services and the type of family planning method chosen after delivery. It is hoped that students, educational institutions and midwives will jointly improve the quality of services by providing optimal IEC related to family planning and contraception.

Keywords: Homecare, Contraception Tools, Pregnant Women III Trimester

\section{PENDAHULUAN}

Perkembangan penduduk yang tinggi dapat menghambat pertumbuhan

hasil pembangunan, termasuk 
pembangunan kesehatan. Keberhasilan

Keluarga Berencana (KB) akan berpengaruh pada penurunan angka kematian ibu, angka kematian bayi, dan angka kematian balita. Dengan demikian, program KB meningkatkan taraf kesehatan dan kesejahteraan masyarakat. Kehamilan yang tidak diinginkan meningkatkan risiko pada hasil yang buruk pada ibu dan bayi.

Rata-rata dari kehamilan yang tidak diinginkan terjadi pada wanita yang tidak menggunakan alat kontrasepsi, sebagian lainnya kehamilan terjadi pada wanita yang dilaporkan menggunakan kontrasepsi. Oleh karena itu, strategi untuk mencegah kehamilan yang tidak diinginkan termasuk membantu wanita yang berisiko terjadi kehamilan yang tidak diinginkan dan pasangannya dengan memilih jenis kontrasepsi yang tepat dan membantu wanita untuk menggunakan kontrasepsi dengan benar dan konsisten untuk mencegah kehamilan.

Tahun 2010, CDC mengadaptasi pedoman global dari WHO untuk membantu petugas kesehatan melakukan konseling bagi para wanita, laki-laki dan pasangannya mengenai pilihan metode kontrasepsi (RISKESDAS, 2013). Dalam memilih jenis kontrasepsi, wanita harus mempertimbangkan status kesehatan, efek samping potensial, konsekuensi terhadap kehamilan yang tidak diinginkan, besarnya keluarga yang diinginkan, dukungan pasangan, dan norma budaya terhadap jenis $\mathrm{KB}$ terpilih.

Pada masyarakat, kontrasepsi hormonal tidaklah asing lagi. Hampir $80 \%$ akseptor KB memilih KB hormonal. Akan tetapi banyak juga akseptor yang mengeluhkan efek samping KB hormonal sehingga banyak akseptor yang drop out. Tingginya angka drop out dikarenakan masih akseptor belum memahami dengan baik tentang KB hormonal.

Efek samping yang sering ditimbulkan pada akseptor kontrasepsi hormonal adalah mual-mual, sakit kepala, pertambahan berat badan, pembengkakan payudara dan perubahan menstruasi. Efek-efek ini tidak berbahaya, tetapi sering kali terasa tidak nyaman. Tetapi akseptor tidak mengetahui bahwa efek samping tersebut disebabkan oleh kontrasepsi hormonal yang digunakan.

Hormon yang terkandung dalam kontrasepsi hormonal dapat merangsang pusat pengendali nafsu makan di 
hipothalamus yang menyebabkan akseptor makan lebih banyak daripada biasanya karena mempengaruhi rasa lapar, haus, dan hasrat emosional. Hormon estrogen juga menyebabkan peningkatan jumlah deposit lemak dalam jaringan subkutan, selain deposit lemak pada payudara dan jaringan subkutan, estrogen juga menyebabkan deposit lemak pada bokong dan paha yang merupakan karakteristik dari sosok wanita (Nurlinda, 2016).

IUD adalah salah satu alat kontrasepsi yang dirancang untuk mencegah kehamilan dan dipasang di dalam uterus sehingga bisa menghalangi fertilisasi dan mencegah terjadinya nidasi. Beberapa keunggulan penggunaan IUD diantaranya adalah efektifitas tinggi yaitu $0,6 \quad-\quad 0,8$ kehamilan per 100 perempuan dalam 1 tahun pertama pemakaian, tidak ada efek samping hormonal, pada umumnya aman dan efektif, dapat digunakan hingga menopause (Majid NK, 2013). Keluarga Berencana Pasca Persalinan (post partum) adalah pelayanan KB yang diberikan kepada pasien setelah melahirkan sampai kurun waktu 42 hari setelah persalinan. Penggunaan kontrasepsi postpartum dipengaruhi faktor sosioekonomi dan demografi, konseling kontrasepsi saat hamil, pengetahuan dan sikap KB postpartum.

Konseling KB Postpartum berpengaruh terhadap penggunaan kontrasepsi pasca persalinan. Beberapa penelitian menunjukkan bahwa ada peningkatan yang signifikan dalam penggunaan metode kontrasepsi efektif pada wanita melalui penyediaan leaflet dan konseling. Penelitian sebelumnya juga menyebutkan hal yang sama yaitu konseling $\mathrm{KB}$ dapat meningkatkan penggunaan kontrasepsi pada periode postpartum. Konseling KB pada periode antenatal juga telah diimplentasikan di Indonesia, akan tetapi masih tingginya unmet need berdasarkan data SDKI 2007 disebabkan antara lain karena belum optimalnya konseling sebagai sarana komunikasi informasi dan edukasi pelayanan keluarga berencana (KB), ketakutan akan efek samping, serta missed opportunities pelayanan KB pada pasca persalinan.

Pemberian konseling Keluarga Berencana dan metode kontrasepsi selama masa perinatal dapat meningkatkan kesadaran ibu untuk menggunakan kontrasepsi (Khotimah VK, 2016). Homecare adalah pelayanan kesehatan yang berkesinambungan dan komprehensif yang diberikan kepada 
individu dan keluarga ditempat tinggal mereka yang bertujuan untuk meningkatkan, mempertahankan atau memulihkan kesehatan atau memaksimalkan tingkat kemandirian dan meminimalkan akibat dari penyakit (Putra A, 2017).

Sasaran utama homecare adalah ibu hamil trimester III. Asuhan di rumah dipersepsikan lebih hemat biaya, lingkungan rumah yang lebih memberikan efek terapeutik, pemberdayaan keluarga dalam asuhan klien lebih optimal. Layanan tersebut diberikan sesuai kebutuhan ibu hamil yang direncanakan dan dikordinir oleh pemberi layanan (Purwaningsih, 2011).

$$
\text { Konseling KB adalah }
$$
percakapan antara dua pihak yang bertujuan untuk membantu calon peserta KB agar memahami norma kelurga kecil bahagia sejahtera (NKKBS) (Khotimah VK, 2016).

Tujuan penelitian ini untuk menganalisis pengaruh pemberian homecare mahasiswi DIII Kebidanan pada ibu hamil trimester III terhadap jenis metode KB terpilih di Malang.

\section{METODE PENELITIAN}

Penelitian ini menggunakan desain obsevasional dengan pendekatan cross sectional. Sampel yang digunakan adalah ibu hamil yang dilakukan layanan homecare mulai hamil sampai dengan KB. Jumlah sampel sebanyak 67 orang diambil dengan cara purposive sampling.

Kategori homecare adalah sesuai dan tidak sesuai dengan Standar Prosedur Operasional (SPO). Skala data : Ordinal. Jenis KB terpilih adalah jenis alat kontrasepsi yang digunakan ibu nifas. Dengan kategori KB Alami, Kontrasepsi Hormonal, IUD. Skala Data : Nominal. Data dianalisis secara deskriptif dengan tabel distribusi frekuensi dan analitik menggunakan uji chi-squar.

\section{HASIL DAN PEMBAHASAN}

Tabel 1. Distribusi Frekuensi responden berdasarkan Pelayanan Homecare Juli s.d Agustus 2018 di Malang

\begin{tabular}{lcc}
\hline $\begin{array}{l}\text { Pelayanan } \\
\text { Homecare }\end{array}$ & Frekuensi & Prosentase \\
\hline Sesuai & 57 & $85 \%$ \\
Tidak sesuai & 10 & $15 \%$ \\
Total & 67 & $100 \%$ \\
\hline
\end{tabular}

Tabel 1 menunjukkan tentang pelayanan homecare yang dilakukan pada responden. Sebagian besar layanan homecare dilakukan dengan baik atau sesuai dengan SOP sebanyak 85\%. Kategori sesuai dengan SOP ini berdasarkan nilai yang didapatkan oleh mahasiswa minimal 80 untuk syarat 
lulus/sesuai. Dengan kata lain, kategori sesuai $\mathrm{SOP}$ jika $=20$ pertanyaan dijawab Ya.
Tabel 2. Distribusi Frekuensi responden berdasarkan pemilihan alat kontrasepsi Juli s.d Agustus 2018 di Malang.

\begin{tabular}{lcc}
\hline $\begin{array}{l}\text { Pemilihan alat } \\
\text { kontrasepsi }\end{array}$ & Frekuensi & Persentase \\
\hline Alami & 12 & $17,9 \%$ \\
Hormonal & 30 & $44,8 \%$ \\
IUD & 25 & $37,3 \%$ \\
Total & 67 & $100 \%$ \\
\hline
\end{tabular}

Tabel 2 menunjukkan bahwa sebagian besar responden memilih alat kontrasepsi hormonal sebanyak 44,8\%.

Tabel 3. Distribusi silang antara layanan homecare dan Pemilihan alat kontrasepsi Juli s.d Agustus 2018 di Malang

\begin{tabular}{lcccc}
\hline Layanan Homecare & Alkon & Prosentase & & Total \\
& Alami & Hormonal & IUD & \\
\hline Sesuai & $10(17,5 \%)$ & $23(40,4 \%)$ & $24(42,1 \%)$ & $57(100 \%)$ \\
Tidak Sesuai & $2(20 \%)$ & $7(70 \%)$ & $1(10 \%)$ & $10(100 \%)$ \\
Total & $12(17,9 \%)$ & $30(44,8 \%)$ & $25(37,3 \%)$ & $67(100 \%)$ \\
\hline
\end{tabular}

Chi-Square $p=0,132$

Tabel 3. menunjukkan bahwa sebagian besar responden dengan layanan homecare sesuai SOP memilih IUD sebagai alat kontrasepsinya sebesar $42,1 \%$, hampir sama dengan responden dengan layanan homecare sesuai tetapi memilih KB Hormonal yaitu 40,4\%. Sedangkan untuk responden yang diberikan home care tidak sesuai SOP, sebagian besar memilih KB hormonal yaitu $70 \%$.

Hal ini mengindikasikan kecenderungan tidak ada hubungan antara layanan homecare dengan pemilihan alat kontrasepsi. Setelah dilakukan analisis menggunakan uji chisquare didapatkan $P$-Value $=0,132$ lebih besar dari alfa 0,05 yang mempunyai arti tidak ada hubungan yang signifikan antara layanan homecare dengan pemilihan alat kontrasepsi pasca persalinan. Layanan homecare memuat 25 hal yang harus diberikan kepada responden.

Sebagian besar layanan tersebut berupa konseling terkait hal-hal yang berhubungan dengan kehamilan antara 
lain KIE tanda bahaya, asuhan kehamilan, asuhan persalinan, asuhan nifas dan masih banyak lagi. KIE tentang KB hanya ada 1 item dari 25 item. Hal ini berarti KIE yang diberikan untuk layanan homecare tidak terfokus pada KIE KB saja.

Hal ini diduga menjadi penyebab tidak adanya pengaruh layanan homecare terhadap pemilihan alat kontrasepsi. Pengetahuan dapat diperoleh dari berbagai sumber seperti media cetak maupun media elektronik. Responden dalam penelitian ini memperoleh informasi bersumber dari tenaga kesehatan yang memberikan informasi mengenai $\mathrm{KB}$ melalui konseling saat homecare.

Penyuluhan dapat meningkatkan pengetahuan responden tentang $\mathrm{KB}$ sesuai dengan informasi yang diterimanya. Hal tersebut didukung oleh penelitian yang dilakukan oleh Rochmah (2012) dari hasil uji korelasi antara pengetahuan dengan pemakaian alat kontrasepsi jangka panjang, dapat disimpulkan bahwa pengetahuan mempunyai keeratan hubungan yang kuat terhadap pemakaian alat kontrasepsi jangka panjang di wilayah kerja puskesmas Gandus Palembang.

Pengetahuan yang memadai merupakan syarat utama untuk mencapai keberhasilan penggunaan KB. Apabila akseptor KB sudah memiliki pengetahuan cukup tentang $\mathrm{KB}$ maka akseptor tidak akan ragu dalam menggunakan alat kontrasepsi. Berdasarkan penelitian Endah Widoro, 2015 menjelaskan bahwa semakin baik program konseling yang ditunjukkan dengan penjelasan yang meyakinkan, memberikan kesempatan bertanya, penjelasan mudah dipahami, kesediaan memberikan penjelasan dan dilakukan secara berulang akan meningkat minat akseptor untuk mengikuti program KB. Minat adalah kecenderungan hati seseorang yang sangat tinggi terhadap sesuatu dari luar dan sangat berhubungan erat dengan hati sanubari.

\section{SIMPULAN DAN SARAN}

Sebagian besar layanan homecare dilakukan dengan baik atau sesuai dengan SOP sebanyak $85 \%$. Kategori sesuai dengan SOP ini berdasarkan nilai yang didapatkan oleh mahasiswa minimal 80 untuk syarat lulus/sesuai. Dengan kata lain, kategori sesuai SOP jika $=20$ pertanyaan dijawab Ya. Home care yang tidak dilakukan sesuai SOP sebanyak $15 \%$ karena jawaban Ya $<20$ pertanyaan. 
Sebagian besar responden memilih alat kontrasepsi hormonal sebanyak $44,8 \%$ sebagai alat kontrasepsi pasca persalinan. Hasil uji chi-square didapatkan pvalue $0,132>0,05$ yang berarti tidak ada hubungan signifikan antara pelayanan home care dengan pemilihan alat kontrasepsi pasca persalinan.

Diharapkan bisa meningkatkan kemampuan KIE dengan cara meningkatkan pengetahuan, sikap dan keterampilan dalam komunikasi dan materi kehamilan, persalinan, nifas, kespro dan $\mathrm{KB}$.

\section{DAFTAR PUSTAKA}

Ekpenyong, CE, et all. 2013. Lactational Amenorrhoea Method Of Contraception: An In-Depth Study Of Awareness, Knowledge And Practice By Breast Feeding Mothers With Unintended Pregnancies. International Journal of Medicine And Medical Sciences Vol 5(1), Pp. 6-13

Kaneshiro et al. 2010. Long-term safety, efficacy, and patient acceptability of the intrauterine Copper T-380A contraceptive device. USA : International Journal of Women's Health.

Khotimah, VK, et all. 2016. Pengaruh Konseling KB Pada Ibu Hamil Trimester III terhadap Keikutsertaan KB Pasca Persalinan di Kecamatan
Sukowono Kabupaten Jember. e-Jurnal Pustaka Kesehatan, Vol. 4 ( 2).

Kiley, J, Sobrero, A, Glob. libr. 2008. Women's medUse and Effectiveness of Barrier and Spermicidal Contraceptive Methods .,(ISSN: 1756-2228) June 2008.

Majid, NK, et all. 2013. Kontrasepsi Intra Uterine Device (IUD) Di Desa Donoyudan Kecamatan Kalijambe Kabupaten Sragen.

Mutihir, JT. 2011. Quarter of a Century of Female Sterilization in Jos, Central Nigeria. African Journal of Reproductive Health. March 2011; 15(1).

Nurlinda. 2016. Gambaran Tingkat Pengetahuan Akseptor KB Hormonal Tentang Efek Samping Kontrasepsi Hormonal Di Puskesmas Gentungan Kabupaten Gowa.

Purwaningsih. 2011. Gambaran Kebutuhan Home Care Pada Pasien Post Sectio Caesarea Di RS BHAYANGKARA POLDA $D I Y$.

Putra A, et all. 2017.Inovasi Pelayanan Publik Bidang Kesehatan Berbasis Home Care Di Kota Makassar. Jurnal Administrasi Publik. Vol. 3(3).

RISKESDAS. 2013. Pelayanan Keluarga Berencana. Jakarta : Badan Penelitian dan Pengembangan Kesehatan Kementrian Kesehatan RI. 
Shukla, M, et all. 2012. Post-placental intrauterine device insertion - A five year experience at a tertiary care centre in north India. Indian J Med Res 136. September 2012. pp 432-435.

Sinaga J, et all. 2017. Mutiara Home Care. Jurnal Pengabdian Kepada Masyarakat. Vol 23 (4)
Veisi, F. 2013. Comparison of Two Different Injectable Contraceptive Methods: Depomedroxy Progesterone Acetate (DMPA) and Cyclofem. Journal of Family and Reproductive Health. Vol. 7(3) 